\title{
Diode Laser \& Conventional Surgery Treatment, A Comparative Study in Anal Diseases
}

\author{
Basim Ghaib Hussein ${ }^{1}$, Jameel I. Azzawi ${ }^{1}$, Rabah Ali Hussein ${ }^{1}$ \\ ${ }^{1}$ M.B.Ch.B,FICMS (General Surgery), Department of Surgery, Collage of Medicine, Tikrit University. Tikrit, Iraq
}

\begin{abstract}
Anal pain is a common complaint, mostly of benign etiology but with psychological impact \& interferes with life activities. The causes of anal pain usually can be easily diagnosed $\&$ treated with over the counter pain relievers \& hot water soaks.
\end{abstract}

Aim of the Study: To compare the effectiveness of treatment with laser surgery to the traditional type of surgery.

Patients \& Method: A prospective study was conducted on patients admitted to Samarra General Hospital \& a private hospital from first of October 2017 to thirty one of May 2018. Ninety eight patients underwent different traditional \& laser surgical procedures for hemorrhoids, anal fissure \&fistula in ano. Of them, 68 patients $(69.3 \%)$ were males \& 30 patients $(30.7 \%)$ were females with age range from $20-55$ years (mean age of 32 year). The patients were divided into 2 groups:

Group A (49 patients) were treated by traditional method \& Group B (49 patients) were treated by laser surgery.

Results: The laser surgery was less than traditional surgery in duration of operation by 17 minutes. For the intraoperative blood loss the laser surgery was less than traditional surgery. The infection rate was 1 of 49 cases in laser surgery while it was 7 of 49 cases in traditional surgery. The healing duration in laser surgery was less than traditional surgery. Duration of return to work was 22 days $\& 23$ days in laser $\&$ traditional surgeries respectively. Finally the pain score according to numeric pain scale was mild for laser surgery \& moderate for traditional one.

Conclusion: Laser surgery was better than traditional surgery in treatment of anal disease.

Key words: Laser surgery, Diode laser surgery, conventional surgery treatment, hemorrhoid, anal fissure, Fistula in ano

\section{Introduction}

Anorectal diseases are a group of medical disorders that occur at the junction of the anal canal \& the rectum, these diseases are commonly encountered in general surgical practice. Patients with diseases of the anus \& rectum are some of the most miserable people in the

\section{Corresponding author: \\ Basim Ghaib Hussein, \\ Department of Surgery, Collage of Medicine, Tikrit University. Tikrit, Iraq. Email: dr.jamel@tu.edu.iq. Phone No: 00964-7719330585}

world. These patients are usually in pain, often anxious $\&$ frequently embarrassed by the examination. Doctors need to be reassuring \& explain clearly what is to be. Anorectal diseases are common, \& their prevalence in general population is probably much higher than that seen in clinical practice as most patients do not seek medical attention ${ }^{1}$. These affect men $\&$ women of all ages. The spectrum of anorectal disorders ranges from benign \& irritating (pruritis ani) to potentially life threatening (anorectal cancer). The evaluation of patients is sometimes made difficult by nonspecific symptoms ${ }^{2}$. The evaluation of anorectal diseases comprises of a careful history \& physical examination before the patient 
can be subjected to various investigations.

The scalpel and conventional electro-surgery unit are the instruments of choice for anorectal surgery. In addition, lasers are an alternative to conventional surgical systems. Scalpels have been used for many years because of their ease of use, accuracy, and minimal damage to the surrounding tissue. On the other hand, scalpels cannot provide the hemostasis that is helpful for use on highly vascular tissue ${ }^{3}$. One characteristic difference between a laser and scalpel cut is the generation of coagulated tissue layer along the walls of the laser incision ${ }^{4}$. All laser tissue interaction produce some degree of tissue vaporization and surrounding zone of thermal necrosis ${ }^{5}$.

This zone of thermal damage should ideally be kept to a minimum, as it may impede wound healing and graft take, and reduce tensile strength ${ }^{4}$. Advantages of this tool include greater precision, a relatively bloodless surgical and postsurgical course, sterilization, vaporization, and cutting, minimal or no suturing, and much less or no postsurgical pain ${ }^{6-8}$. The factors that determine the initial tissue effect include the laser wavelength, laser powder, the available laser waveform (continuous wave, chopped, and pulsed beams), and tissue thermal properties ${ }^{9}$.

Laser beams can burn or destroy healthy tissue, cause injuries that are painful and sometimes permanent. All of the above risks, precautions, and potential complications should be discussed by the doctor with the patient. The nature and severity of the problem, the skill of the surgeon preforming the procedure, and the patient's general health and realistic expectations are among the factors that influence the outcome of laser surgery ${ }^{11}$.

\section{Patients and Method}

A prospective study was conducted upon patients admitted into Tikrit Teaching Hospital and a private hospital from $1^{\text {st }}$ of October 2013 to $31^{\text {th }}$ of May 2014. Ninety eight patient underwent different traditional and laser surgical procedures for hemorrhoid, anal fissure, fistula in ano. Patients were divided randomly in to two groups: Group A (49 patients) were treated by traditional (scalpel) method, and Group B (49 patients) were treated by laser surgery. Different types of operations with different levels of complexity are done for example:

For hemorrhoids:

One pile are removed, two piles, three piles.
For anal fissure:

-Lateral internal sphincteretomy.

-anal dilation and skin tag removal.

For fistula in ano:

Fistulotomy, fistuloctomy for low anal fistula and seton for high anal fistula.

All these operations are done after full preparation of the patients which include detailed history bright red painless bleeding mucus discharge, prolapse and pain. Examination and digital rectal examination (DRE), proctoscopy and sigmoidoscopy were performed. Full investigations are send (complete blood picture, renal function test, liver function test, viral cardiography for elderly patients. The operations are done under general anesthesia, spinal anesthesia, local anesthesia and the patients in the lithotomy position, patients were discharge within 4 to 12 hours, and were followed for 3 to 4 weeks for healing progress and complications.

\section{Inclusion and exclusion criteria}

\section{Inclusion Criteria}

1. Patients with hemorrhoid.

2. Patients with anal fissure.

3. Patients with fistula in ano.

4. Patients with anal fissure or fistula in ano associated with inflammatory bowel

\section{Exclusion Criteria}

1. Patients diagnosed with these diseases and associated with malignancy.

\section{Preparation of the Diode Laser device}

First, we have to check the device by observation of the continued type of electricity and the device should be loaded by load system, then when the device opened, we should put the program suitable for the type of the anal pathology. If the pathology is anal fissure or fistula we should press on the option of continues cutting as shown by program (1) and if the pathology is hemorrhoid we use either (continuous cutting) and we should ligate the pedicle with No. 0-1 vicry1, or in case of giving (impulse type) we should give each pile (7) Jull, the total power given is (21) if three piles removed which is the 
maximum power you can give. Finally, the procedure is like the conventional surgery but with the use of laser instead of scalpel.

\section{Results}

In this series of 98 patients, the patients presented with hemorrhoid anal fissure, fistula in ano are operated on. The frequency distribution of cases in each group are according to gender and as shown in the table (1)

Table (1) Male and Female distribution of cases

\begin{tabular}{|l|l|l|l|l|l|l|}
\hline \multirow{2}{*}{ Disease } & \multicolumn{2}{l}{ Traditional Surgery } & \multicolumn{2}{l|}{ Laser Surgery } \\
\cline { 2 - 8 } & Male & Female & Total & Male & Female & Total \\
\hline hemorrhoid & 21 & 5 & 26 & 23 & 3 & 26 \\
\hline Anal fissure & 10 & 6 & 16 & 6 & 11 & 17 \\
\hline Fistula in ano & 4 & 3 & 7 & 4 & 2 & 6 \\
\hline Total & 35 & 14 & 49 & 33 & 16 & 49 \\
\hline
\end{tabular}

In hemorrhoid traditional surgery the range of time from (15-25) min. with mean time of surgery 20 minute while laser surgery the range of time from (12-18) min. with mean time 15 minute.

In anal fissure traditional surgery the range of time from (12-17) min. with mean time 15 minute while in laser surgery the range of time from (8-13) min. and mean time 9 minute.

In fistula in ano traditional surgery the range of time from (13-27) min. with mean time 18 minute while the laser surgery the range of time from (10-22) min. with mean time 12 minute.

Table (2) Intraoperative amount of blood loss/ $\mathrm{ml}$

\begin{tabular}{|l|l|l|l|l|l|}
\hline \multirow{2}{*}{ Disease } & \multicolumn{2}{|l|}{ Traditional Surgery } & \multicolumn{2}{l|}{ Laser Surgery } & \multirow{2}{*}{ Difference } \\
\cline { 2 - 6 } & Range of blood loss & SD & Range of blood loss & SD & \\
\hline hemorrhoid & $(10-25) \mathrm{ml}$ & $20 \mathrm{ml}$ & $(8-17) \mathrm{ml}$ & $12 \mathrm{ml}$ & $8 \mathrm{ml}$ \\
\hline Anal fissure & $(6-20) \mathrm{ml}$ & $10 \mathrm{ml}$ & $(4-11) \mathrm{ml}$ & $5 \mathrm{ml}$ & $5 \mathrm{ml}$ \\
\hline Fistula in ano & $(7-20) \mathrm{ml}$ & $12 \mathrm{ml}$ & $(5-13) \mathrm{ml}$ & $7 \mathrm{ml}$ & $5 \mathrm{ml}$ \\
\hline Total & & $42 \mathrm{ml}$ & & $24 \mathrm{ml}$ & $18 \mathrm{ml}$ \\
\hline
\end{tabular}

It can noticed from table (2) the following observations:

- The amount of intraoperative blood loss was measured by weighing of the gauze. In which every $1 \mathrm{gm}=1 \mathrm{ml}$.

-In traditional hemorrhoid surgery the range of amount of blood loss from (10-25) $\mathrm{ml}$, with mean amount of $20 \mathrm{ml}$. while the range of amount of blood loss from $(8-17) \mathrm{ml}$ with mean amount of $8 \mathrm{ml}$ in laser surgery.
- In traditional anal fissure surgery the range of amount of blood loss from (6-20) ml, with mean amount of $10 \mathrm{ml}$. while the range of amount of blood loss from (4-11) $\mathrm{ml}$ with mean amount of $5 \mathrm{ml}$ in laser surgery.

- In traditional fistula surgery the range of amount of blood loss from (7-20) $\mathrm{ml}$, with mean amount of $12 \mathrm{ml}$. while the range of amount of blood loss from (5-13) $\mathrm{ml}$ with mean amount of $7 \mathrm{ml}$ in laser surgery. 
Table (3) Rate of infection

\begin{tabular}{|l|l|l|l|l|l|l|}
\hline \multirow{2}{*}{ Disease } & \multicolumn{2}{|l|}{ Traditional Surgery } & \multicolumn{2}{l|}{ Laser Surgery } \\
\cline { 2 - 7 } & $\begin{array}{l}\text { No. of } \\
\text { infected cases }\end{array}$ & $\begin{array}{l}\text { No. of } \\
\text { operated cases }\end{array}$ & $\%$ & $\begin{array}{l}\text { No. of } \\
\text { infected cases }\end{array}$ & $\begin{array}{l}\text { No. of } \\
\text { operated cases }\end{array}$ & $\%$ \\
\hline hemorrhoid & 2 & 26 & 7.6 & 0 & 26 & 0 \\
\hline Anal fissure & 2 & 16 & 12.55 & 0 & 17 & 0 \\
\hline Fistula in ano & 3 & 7 & 42.8 & 1 & 6 & 16.6 \\
\hline Total & 7 & 49 & 14.2 & 1 & 49 & 2.04 \\
\hline
\end{tabular}

Figure (1) infection rate in traditional anal surgery

Figure (2) infection rate in Laser anal surgery

It can be notice from table (3) and Figure 1 and 2 the following observations:

-In traditional hemorrhoid surgery the number of infected cases were 2 of $26(7.6 \%)$, while in laser surgery the number of infected cases were 0 of $26(0 \%)$.

- In traditional anal fissure surgery the number of infected cases were 2 of $16(12.55 \%)$, while in laser surgery the number of infected cases were 0 of $17(0 \%)$.

- In traditional fistula surgery the number of infected cases were 3 of $7(42.8 \%)$, while in laser surgery the number of infected cases were 2 of $6(16.6 \%)$.

Finally the total number of infected cases in traditional surgery were 7 of $49(14.2 \%)$, while the total number of infected cases in laser surgery were 1 of $49(2.04 \%)$.

Table (4) Mean healing duration/Day

\begin{tabular}{|l|l|l|l|l|l|}
\hline \multirow{2}{*}{ Disease } & \multicolumn{2}{|l|}{ Traditional Surgery } & \multicolumn{2}{l|}{ Laser Surgery } & \multirow{2}{*}{ Difference } \\
\cline { 2 - 6 } & Range of Time & SD & Range of Time & SD & \\
\hline hemorrhoid & $(18-30)$ day & 25 day & $(15-24)$ day & 19 day & 6 day \\
\hline Anal fissure & $(14-24)$ day & 20 day & $(10-15)$ day & 11 day & 9 day \\
\hline Fistula in ano & $(14-27)$ day & 21day & $(12-18)$ day & 14day & 7 day \\
\hline Total & & 66 day & & 44day & 22day \\
\hline
\end{tabular}

It can be notice from table (4) the following observations:

-In traditional hemorrhoid surgery the range of healing from (18-30) day with mean time 25 day, while in laser hemorrhoid surgery the range of healing from (15-24) day with mean time 19 day.
- In traditional anal fissure surgery the range of healing from (14-24) day with mean time 25 day, while in laser anal fissure surgery the range of healing from (10-15) day with mean time 11 day.

- In traditional fistula surgery the range of healing from (14-27) day with mean time 21 day, while in laser fistula in ano surgery the range of healing from (12-18) 
day with mean time 14 day.

\section{Discussion}

When the people think of surgery the first thing that comes to mind is the knife. The thought of being cut can turn many people off from getting much needed medical procedures. With the advancements in medical technology and the advent of laser surgery, more people can feel at ease when contemplating major surgery or simple cosmetic procedure. This may be used to seal off blood vessels to help reduce blood loss during surgery along with being able to help seal off infected areas. This is all done with minimal damage to the surrounding area $^{12}$.

The other advantage of laser surgery is that it may be used to seal nerve endings. This is especially helpful in reducing pain in areas that have undergone recent surgery. This makes it great alternative to pain medications and their side effects although this type of surgery is not without its own side effects ${ }^{12}$.

There are several studies that were done for comparison between laser and traditional methods in anal diseases, but these studies are different either in laser type used such as $\mathrm{CO}_{2}{ }^{(13)}$ or difference in the procedure itself $^{(14)}$. There is no similar of our work to compare with it for diode laser results, so we will compare just for traditional surgery results.

The present study revealed that total difference in duration time between the two methods was less in laser surgery by 17 minute for the three operations. The traditional surgical hemorrhoidectomy agreed with Towlait K. SM. (2012) ${ }^{15}$.

For postoperative infection the difference was 6 patients less in diode laser surgery. Seven patients for traditional surgery (14.2\%), and 1 patients for laser surgery $(2.04 \%)$. The traditional hemorrhoidectomy method agreed with Uba A.F. (2004) ${ }^{16}$. This decrease in rate of infection because production of an eschar layer ${ }^{17}$.

In our study we documented that the postoperative pain for traditional surgery was moderate according to (numeric pain scale), In our research in spite of differences that shown in duration of operation, intraoperative blood loss, wound infection rate, duration of healing, duration of return to work, and postoperative pain. The $\mathrm{P}$ value was more than 0.05 by SD.
By the analysis of our work we have found that the cause of being (not significant) because:-

1. Small sample size selection in comparison to this common conditions, because of short time for collection of data.

2. We compare the two procedure with three type of disease so the results more sub-divided that lead to be not significant.

3. In spite of decrease in blood loss with the laser surgery, the blood loss in traditional surgery is not large amount (collected procedure), so the difference is not sufficient to make the amount significant in this study.

4. In spite of the difference in the results of healing time and time to return to work but the small sample size and multiple diseases lead to be not significant.

5. As we mentioned, the postoperative pain is subjective experience, and measured by numeric pain score, so it was not examined by SD.

\section{Conclusions}

1. Decrease in duration of operation that is important for the patient and surgeon, which is also important in decreasing of time exposure to anesthesia.

2. In spite of small amount of blood loss in these operations the laser made it almost bloodless field.

3. The postoperative pain is very important for the patients, which also decrease the need for postoperative analgesia.

4. Decreasing the postoperative infection rate is very important for the patient early healing, early return to work and economically very effective.

Conflict of Interest - (nil - There are "No Conflict of Interest").

Source of Funding - By all

Ethical Clearance: Committee members are approved to perform a study about:

"Diode laser \& conventional surgery treatment, a comparative study in anal diseases"

After discussion of study plan with researchers:

Researchers: 
1. Dr. Basim Ghaib Hussein

2. Dr. Jameel I. Azzawi

3. Dr. Rabah Ali Hussein

\section{References}

1. Gopal DV. Diseases of the return and anus: a clinical approach to commons. Clin Cornerstone 2002; 4(4): 34-48.

2. Lacy BE, Weiser K. common anorectal disorders: diagnosis and treatment. Curr Gastroenterol Rep 2009 Oct; 11(5): 413-9.

3. Liboon J, Funkhouse W, Terris D. comparison of mucosal incisions made by scalpel, $\mathrm{CO}_{2}$ laser, electrocautery and constant- voltage electrocautery. Otalaryngol Head Neck Surg 1997; 116:379-385.

4. Wilder- smith P, Arrastia AM, Liaw LH, Berns M. Incision properties and thermal effects of thoursee $\mathrm{CO}_{2}$ lasers in soft tissue. Oral Surg Oral Med Oral Pathol Oral Radiol Endod 1995; 79:685-691.

5. Wilder- smith P, Dang J, Kurosaki T. Investigating the range of surgical effects on soft tissue produced by a carbon dioxide laser. J Am Dent Assoc 1997; 128:583-588.

6. Pick RM, Colvard MD. Current status of lasers in soft tissue dental surgery. J Periodontal 1993; 64:589-602.

7. Gold SI, Vilardi MA. Pulsed laser beam effects on gingiva. J Clin periodontal 1994; 21:391-396.
8. White JM, Goodis HE, Rose CL. Use of the pilsed $\mathrm{Nd}$ : YAG laser for intraoral soft tissue surgery. Lasers Surg Med 1991; 11:455-451.

9. Douglas N, Dederich NH. Laser/ tissue interaction. Alpha Omegan 1991; 84:33-36.

10. Carlson Karen J., et. al. the Harvard Guide to Women's Health. Cambridge, MA: Harvard University Press, 1996.

11. Haggerty, Maureen. "ASLMS Guidelines for office-Based Laser Procedures." A Healthy Me Page. 19 Mar.1998.

12. Mike W. Andrew. The many advantages of laser surgery over Traditional Surgery. Go Articles.2010.

13. Saad H., Sultan M., et. al. Is $\mathrm{CO}_{2}$ Laser Hemorrhoidectomy Superior to Conventional Open Hemorrhoidectomy? Al- Kindy College of Medicine Journal.2010; vol.6:pp.1.

14. Mohamed K. Interstitial Photocoagulation of Low Anal Fistula Using 810 Diode Laser Prospective Study. Iraqi Journal Laser.2004; vol.3:pp.43-50.

15. Towliat K., Mehrvarz S., Mousavi SM., and et. al. Milligan Morgan Hemorrhoidectomy versus Stapled Hemorrhoidopexy. Journal of Trauma and Emergency Medicine.2012; vol.16:175-177.

16. Uba A.F., Obecpa P.O., and Ardill W. Open versus closed Hemorrhoidectomy. Niger postgraduate Medical Journal.2004; vol.11:79-83.

17. Pirnat S. Versatility of an $810 \mathrm{~nm}$ Diode laser in dentistry: An overview. LAHA 2007; 4:1-9. 